\title{
Roberto González Ramos y Jesús María Ruiz Carrasco (eds.), Arte y nobleza. El diletantismo artístico en la Edad Moderna, Córdoba, UCOPress-Editorial Universidad de Córdoba, 2019, 336 pp. ISBN: 978-84-9927-478-2
}

Pablo Allepuz García

Instituto de Historia, CSIC

ESPAÑA

pablo.allepuz@cchs.csic.es

Hipogrifo, (issn: 2328-1308), 8.2, 2020, pp. 875-878

Recibido: 15-10-2020 / Aceptado: 28-10-2020

DOI: http://dx.doi.org/10.13035/H.2020.08.02.52

En el ámbito de la historia del arte, tan importante es pensar las imágenes como pensar con las imágenes, pues estas a menudo llegan donde las palabras no alcanzan. W. J. T. Mitchell o K. Moxey han demostrado hasta qué punto la écfrasis es a la vez fundamento y límite de los estudios sobre manifestaciones visuales: fundamento porque nos permite figurar algunas respuestas ante el fenómeno - por definición inefable- de la expresión plástica; y límite porque, al hacerlo, las preguntas originales -irreductibles al lenguaje- quedan desfiguradas, cuando no ocultas u olvidadas.

Los editores de Arte y nobleza. El diletantismo artístico en la Edad Moderna, Roberto González Ramos y Jesús María Ruiz Carrasco, parecen reconocer esta complejidad ya desde la misma cubierta del volumen. Junto a tan ilustrativo título - la cópula de arte y nobleza es clave- incorporan el Autorretrato pintando el retrato de su hijo Francisco de Félix Machado, marqués de Montebello, uno de esos documentos gráficos que retroalimentan el círculo hermenéutico casi hasta el infinito. ¿Qué condicionantes históricos llevan a un personaje de alta alcurnia a dedicar su tiempo a la práctica artística, considerada hasta poco antes mero trabajo artesanal? ¿Qué repercusión tiene este nuevo agente del campo cultural sobre la figura del artista profesional y su reconocimiento por parte de la sociedad? ¿Qué discipli- 
nas artísticas privilegian estas dinámicas sociales y qué nueva jerarquía establecen entre unas bellas artes en constante parangón? ¿Qué inspiraciones abstractas o modelos concretos guían tales comportamientos? ¿Qué estrategias identitarias operan en el hecho de proyectar la imagen -pública o privada- a través de un (sub)género tan connotado como el autorretrato? ¿Qué legitimación genealógica persigue al introducir a su vez dentro del autorretrato un retrato de su hijo, superponiendo el parentesco al parecido y por tanto -como la crítica feminista cuestionará más tarde- la procreación a la creación? ¿Qué papel cumple la inscripción redundante del nombre propio - el nombre del padre, la firma del artista- en el espacio de la representación? ¿Qué lecciones podemos extraer de todo ello en el presente?

Doce capítulos afrontan estas y otras preguntas desde distintos puntos de vista, como corresponde a un asunto de semejante calado y despliegue cronológico: en lugar de un relato maestro, continuo y totalizador, la multiplicidad de voces, objetos y enfoques permite dar cuenta de los matices del problema abordado con mucho mayor detalle; no en vano este resultado viene avalado por varios años de trabajo en común en el marco del proyecto de investigación «El desarrollo de la cultura aristocrática hispana: educación de la nobleza y práctica de las artes figurativas (1580-1800)». De ahí que pueda mantenerse una coherencia metodológica -casi siempre a partir de presupuestos de la sociología del arte- a través de textos heterogéneos que van desde las visiones de conjunto hasta el estudio de casos, desde el análisis de reflexiones teóricas hasta la interpretación de ciertas obras, desde la arquitectura o la ingeniería hasta la pintura o el dibujo.

Siguiendo un buen criterio editorial, el volumen arranca con la contribución de Adolfo Carrasco Martínez, «Elegir la excelencia. Ética y condición nobiliaria (ca. 1600)», que sitúa los debates sobre el estatus de la nobleza en un escenario transnacional europeo y en línea tanto con su herencia grecolatina como con su orientación cristiana: probablemente sea la concepción moral de lo que implicaba ser noble entonces -ya como individuo, ya como colectivo- aquello que permita inducir o deducir cualidades excepcionales en su relación con las creaciones artísticas. Junto a esta elaboración conceptual, Roberto González Ramos -investigador principal del citado proyecto- desarrolla los dos capítulos más extensos, que de alguna manera sirven como fondo sobre el que se recortan los demás. En el primero de ellos, «Nobleza y ejercicio de las artes en el Seiscientos hispano. Educación, placer y función social», propone un recorrido por estas tres nociones que articulan ideológicamente el acceso de los nobles a las bellas artes y ensaya una nómina de ellos fundamentalmente a partir de la tratadística. El segundo, «Academia, nobleza y ejercicio del dibujo y la pintura en la España del siglo XVIII», completa la secuencia histórica atendiendo a la institucionalización de dichas prácticas y el rol cada vez más central de los nobles en la vida artística nacional.

Esta panorámica general, necesaria para comprender la materia en toda su amplitud, va adquiriendo perfiles específicos en otras partes del libro. José Antonio Guillén Berrendero presenta un tema crucial en su «Las que el vulgo llama armas 
y los heraldos, armerías que son señales de nobleza: la heráldica, una definición visual de nobleza en la Monarquía de España durante el siglo XVII», por cuanto tiene el blasón de discurso de honor -y de poder- inserto en un sistema de comunicación visual con códigos propios. Begoña Alonso Ruiz, en «Comitentes, diletantes y arquitectos: nobles y arquitectura en la Edad Moderna», desgrana la trascendencia de la idea de magnificencia en la construcción -física y simbólica- de la distinción nobiliaria a través de la promoción edilicia. Manuel Gámez Casado señala la importancia de los «Nobles en el Real Cuerpo de Ingenieros Militares», un vínculo sostenido durante décadas por la tradición y que resultó vital para el posterior asentamiento de su categoría profesional. Jesús María Ruiz Carrasco estudia la presencia de «Nobles y aficionados ilustres en las matrículas de la Real Academia de San Fernando», uno de los indicadores más sensibles del proceso de implantación de preceptos estéticos ilustrados y también factor determinante en la renovación de las élites españolas. David García López, en «Nobles y practicantes de la pintura según el ideario de Juan Agustín Cean Bermúdez: la educación y el fomento de las Bellas Artes», abunda en el doble carácter didáctico y reivindicativo de la literatura sobre arte en la época. Luis de Moura Sobral, en «Ecco i disegni delle auguste donne. Nobles portugueses aficionados a la pintura (siglos XVII-XIX)», expone por su parte el estado de la cuestión y los principales casos lusos, entre los cuales volvemos a encontrar al fascinante marqués de Montebello -autor además de una «autobiografía» que quedó manuscrita-.

Por último, otros tres capítulos profundizan en ese entramado a través de individuos cuyas historias resultan representativas de ciertas tendencias o de excepciones a las mismas. Alfredo J. Morales se centra en «Diego Ortiz de Zúñiga, noble, caballero veinticuatro, historiador y diletante», personaje de vasta cultura que nos legó un conjunto de dibujos sobre arquitectura -el Álbum D. Z.- único en el Seiscientos español. Javier González Santos dedica su aportación a «Cosme Bernardo de Palacio: un aficionado y coleccionista de pintura en el funcionariado y pequeña nobleza del siglo XVIII», pintor diletante asturiano rescatado del olvido para esta ocasión. Letizia Gaeta, en «L'idea di nobiltà nell'arte napoletana della seconda metà del Cinquecento. II ruolo di Giulio Cesare Capaccio nell'educazione degli artisti e due casi di pittori aristocratici», invierte el orden de otras intervenciones para ir de lo particular de los escritos de Capaccio a lo general del diletantismo en el sur de Italia.

La inclusión de los capítulos sobre Nápoles y Portugal no solo supone un «complemento imprescindible del presente volumen» como se apunta en las notas introductorias, sino que confirma esa transversalidad internacional defendida por Carrasco -reenviando de nuevo al comienzo- y permitiría tal vez extrapolar conclusiones para un estudio comparado. En definitiva, el libro tiene la virtud de ofrecer respuesta a un problema de largo alcance, poco atendido hasta el momento por la historiografía, con una aproximación ambiciosa respaldada por la participación de investigadores de nueve universidades distintas. Pero también tiene la virtud, tal vez mayor, de dejar planteadas nuevas incógnitas para resolver - o no- en el futuro. Algunas están sugeridas en los textos, y por ejemplo sería interesante rastrear 
las transformaciones del diletantismo a lo largo de la época contemporánea; otras están contenidas en las hasta setenta y seis imágenes a todo color - la mayoría también a toda página- que demuestran la especial atención a estos materiales por parte de los editores y que por desgracia son cada vez menos habituales en nuestras publicaciones especializadas. Arte y nobleza. El diletantismo artístico en la Edad Moderna marca un hito en su campo de estudio y es de esperar que motive nuevas contribuciones científicas en los próximos años. 